\title{
Community heterogeneity of aquatic macroinvertebrates in urban ponds at a multi-city scale
}

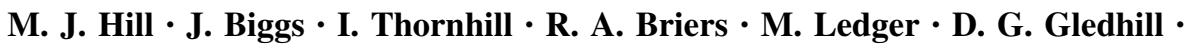 \\ P. J. Wood $\cdot$ C. Hassall 10
}

Received: 5 July 2017 / Accepted: 3 January 2018/Published online: 17 January 2018

(C) The Author(s) 2018. This article is an open access publication

\begin{abstract}
Purpose Urbanisation is a leading cause of biotic homogenisation in urban ecosystems. However, there has been little research examining the effect of urbanisation and biotic homogenisation on aquatic communities, and few studies have compared findings across different urban landscapes. We assessed the processes that structure aquatic macroinvertebrate diversity within five UK cities and characterise the heterogeneity of pond macroinvertebrate communities within and among urban areas.

Methods A total of 132 ponds were sampled for invertebrates to characterise biological communities
\end{abstract}

Electronic supplementary material The online version of this article (https://doi.org/10.1007/s10980-018-0608-1) contains supplementary material, which is available to authorized users.

M. J. Hill

Institute of Science and the Environment, University of

Worcester, Worcester, Worcestershire WR2 6AJ, UK

J. Biggs

Freshwater Habitats Trust, Bury Knowle House,

Headington, Oxford OX3 9HY, UK

I. Thornhill

The College of Liberal Arts, Bath Spa University, Newton

St. Loe, Bath BA2 9BN, UK

R. A. Briers

School of Applied Sciences, Edinburgh Napier

University, Edinburgh EH11 4BN, UK of ponds across five UK cities. Variation among sites within cities, and variation among urban settlements, was partitioned into components of beta diversity relating to turnover and nestedness.

Results We recorded 337 macroinvertebrate taxa, and species turnover almost entirely accounted for the high beta-diversity recorded within each urban area and when all ponds were considered. A total of $40 \%$ of all macroinvertebrates recorded were unique to a particular urban settlement. In contrast to the homogenisation of terrestrial and lotic communities in urban landscapes reported in the literature, ponds support highly heterogeneous communities within and among urban settlements.

Conclusions The high species turnover (species replacement) recorded in this study demonstrates that urban pond biodiversity conservation would be most

I. Thornhill · M. Ledger

School of Geography, Earth and Environmental Sciences,

University of Birmingham, Edgbaston,

Birmingham B15 2TT, UK

D. G. Gledhill

School of Environment and Life Sciences, Ecosystems and Environment Research Centre, University of Salford, Peel Building, Salford, Greater Manchester M5 4WT, UK

P. J. Wood

Department of Geography, Centre for Hydrological and

Ecosystem Science, Loughborough University,

Loughborough, Leicestershire LE11 3TU, UK 
efficient at a landscape-scale, rather than at the individual ponds scale. Pond conservation practices need to consider the spatial organization of ecological communities (landscape-scale) to ensure that the maximum possible biodiversity can be protected.

Keywords Beta-diversity - Landscape-scale conservation - Lentic habitat - Species turnover . Anthropogenic landscape

\section{Introduction}

Ponds are dynamic habitats that support significant biological diversity and provide important ecosystem services globally (Hill et al. in review; Biggs et al. 2017; Stewart et al. 2017; Vad et al. 2017). There has been a significant increase in research attention directed towards pond habitats and their biota in recent years (Cereghino et al. 2014), yet the majority of studies have focussed on ecological communities among ponds in rural and agricultural landscapes (e.g., Usio et al. 2013; De Marco Jr et al. 2014; Simaika et al. 2016). By contrast, urban ponds have received less research attention globally (see Hassall 2014), despite predictions that global urban land coverage is set to increase by 1.2 million $\mathrm{km}^{2}$ by 2030 (Seto et al. 2012). Urban ponds are typically of anthropogenic origin, and often display a wide range of environmental conditions (Hill et al. 2015) reflecting the diversity of habitats and locations where they occur including private gardens (Gaston et al. 2005; Hill and Wood 2014), industrial areas (Wood et al. 2001), public parks (Hassall 2014) and at the margins of roads (e.g., stormwater ponds: Hassall and Anderson 2015). They have typically been constructed for purposes other than biodiversity conservation i.e. for flood prevention/stormwater collection, sediment capture, water purification and for aesthetics (Lundy and Wade 2011). As a result, some urban ponds may suffer from contamination from heavy metals and other pollutants while others may be almost pristine due to intensive

\footnotetext{
C. Hassall ( $\bowtie)$

Faculty of Biological Sciences, School of Biology, University of Leeds, Woodhouse Lane, Leeds LS2 9JT, UK

e-mail: c.hassall@leeds.ac.uk
}

conservation management to enhance ecological communities.

Urbanisation has led to the destruction of natural habitat and the creation of a more artificial, uniform landscape (Tratalos et al. 2007). Conversion to urban land cover has altered natural geomorphological and hydrological processes (O'Driscoll et al. 2010), nutrient cycling ( $\mathrm{Gu}$ et al. 2012; Kaushal et al. 2014), reduced soil and water quality (Shao et al. 2006) and exacerbated climate variability (urban heat island effect; Streutker 2003), resulting in disturbance and chronic stresses on flora and fauna inhabiting these areas (Alberti 2005; McKinney 2008; Ortega-Alvarez and MacGregor-Fors 2009). These effects have typically led to reduced biotic diversity in urban areas (although greater diversity of floral communities has been recorded at moderate levels of urbanisation; McKinney 2008) and increasingly fragmented and isolated remnant natural habitat patches (Stepenuck et al. 2002; Chace and Walsh 2006; Pauchard et al. 2006). In particular, urbanisation is a primary cause of biotic homogenization (McKinney 2006; Knop 2016). Local extinctions of indigenous taxa sensitive to changes in environmental conditions have resulted in replacement by synanthropic, disturbance tolerant taxa able to exploit urban habitats (McKinney 2006). Homogenisation is a common phenomenon in urban terrestrial and lotic habitats, although there may be scale dependence in the response to urbanisation, with some evidence from avian and plant communities that at a global scale homogenisation is less evident (Aronson et al. 2014).

While the detrimental effects of urbanisation (e.g., reduced diversity) have been extensively documented for terrestrial (Holway and Suarez 2006; Sol et al. 2014; Knop 2016) and lotic systems (Roy et al. 2003; Walters et al. 2003), ponds have recently been found to follow a different trajectory. Although some studies have reported lower faunal diversity in urban ponds, reflecting management practices for purposes other than biodiversity (Noble and Hassall 2014), others have found urban ponds to support similar faunal diversity to ponds in non-urban settings (Hassall and Anderson 2015; Hill et al. 2017a). Urban ponds may thus serve as refuges and stepping stones for aquatic taxa moving between natural habitat patches. In nonurban landscapes, ponds have been demonstrated to have high community dissimilarity (greater than other waterbodies) driven by their discrete, small 
catchments which promote heterogeneous physical and chemical conditions (Davies et al. 2008a, b) and the large influence of stochastic processes (Jeffries 1988). The wide environmental heterogeneity among urban ponds and their relatively high frequency of occurrence suggests that complex networks of ponds exist in urban areas, promoting high community heterogeneity (Hassall 2014; Hill et al. 2017a). However, the effect of urbanisation on community heterogeneity among urban ponds at a multi-city scale has not previously been considered.

The continued expansion of urban land cover globally has led to a need to pursue biodiversity conservation in urban areas at multiple spatial scales (Socolar et al. 2016). Beta-diversity, (the compositional differences between local assemblages) which describes how communities are organised in space, can provide conservation relevant information to protect biological diversity (Rickbeil et al. 2014). Beta diversity can be separated into two components: (1) species turnover, which reflects the replacement of taxa from one site by others in different sites and is typically a response to high environmental heterogeneity and biotic competition within sites; and (2) nestedness which occurs when species poor sites are subsets of sites with species rich communities (Baselga 2010; Corti and Datry 2015; Gianuca et al. 2016). Beta-diversity is rarely organised by species turnover and nestedness separately, but is often structured by varying contributions of nestedness and turnover. While there has been increasing research on nestedness and turnover in non-urban areas (e.g., Brendonck et al. 2015; Viana et al. 2016) there has been little research attention focussed on the organisation of beta-diversity in highly disturbed environments such as urban ponds. Urban ponds may demonstrate a different spatial organisation of biodiversity compared to non-urban ponds given the very different architecture and levels of disturbance (Heino et al. 2017). Examining and understanding beta-diversity within and among pond assemblages within urban settlements could inform the future placement and design of sites, supporting networks of protected aquatic habitats (city parks or urban wildlife conservation areas) and the management of invasive species within urban areas at an inter-city scale (Socolar et al. 2016). In addition, incorporating beta-diversity into conservation strategies could provide the detailed information required to deliver the most cost effective and efficient biodiversity conservation possible in anthropogenically dominated landscapes (Socolar et al. 2016).

To our knowledge, this is the first study to examine the aquatic macroinvertebrate beta-diversity in urban ponds across multiple urban settlements. This study specifically aimed to quantify the macroinvertebrate diversity within multiple UK urban settlements and characterise the heterogeneity of macroinvertebrate communities within and among urban areas. It is hypothesised that (1) variation in community structure within each urban settlement and for the entire study region will predominantly be driven by species turnover as highly heterogeneous local habitats result in discrete, rather than nested, communities; (2) there will be high macroinvertebrate community heterogeneity (beta-diversity) within each urban settlement; and (3) there will be high community heterogeneity (beta-diversity) among the urban settlements.

\section{Methods}

\section{Data management}

Urban spaces are defined as areas $>20$ ha containing $>10,000$ people (UKNEA 2011). In England, $>10 \%$ of the total land cover is classified as urban (UKNEA 2011). Macroinvertebrate community data and environmental data from 132 urban ponds from five (5) UK urban settlements (Halton: $\mathrm{n}=25$, Loughborough: $\mathrm{n}=41$, Stockport: $\mathrm{n}=16$, Birmingham: $n=30$ and Huddersfield: $n=20$ ) were collated from previous studies and examined (Table 1; Fig. 1). A wide range of environmental data was collected between the contributing studies with pond area, $\mathrm{pH}$, percentage pond shading, altitude and percentage pond coverage of emergent macrophytes being recorded in most of the studies. However, the percentage of pond shaded was not recorded in study 2 and $\mathrm{pH}$ was not recorded by study 5 . Studies 1, 2, 3 and 4 were sampled across two or three seasons, while study 5 was sampled during the summer season only. Aquatic macroinvertebrate sampling methods undertaken by the five (5) urban pond studies broadly followed the guidelines of the National Pond Survey (Biggs et al. 1998). A three (3) minute sweep sample was undertaken in each urban pond, divided between the microhabitats present (studies 1,2 and 3). The remaining two studies (studies 4 and 5) sampled for 
Table 1 Summary table of the urban settlement size and population size of the study areas and macroinvertebrate sampling method of the 5 contributing studies (adapted from Hill et al. 2017a, pp. 4-5)

\begin{tabular}{|c|c|c|c|c|c|c|}
\hline $\begin{array}{l}\text { Reference } \\
\text { number }\end{array}$ & Location & $\begin{array}{l}\text { Urban } \\
\text { settlement } \\
\text { size }\end{array}$ & Population & Macroinvertebrate sampling method & $\begin{array}{l}\text { Taxonomic } \\
\text { resolution }\end{array}$ & Reference \\
\hline 1 & $\begin{array}{l}\text { Loughborough, } \\
\text { UK } \mathrm{n}=41\end{array}$ & $\sim 35 \mathrm{Km}^{2}$ & 60,000 & $\begin{array}{l}\text { Ponds were sampled during spring, } \\
\text { summer and autumn seasons. } \\
\text { Sampling time was proportional to } \\
\text { pond surface area, up to a maximum } \\
\text { of three minutes. Allocated } \\
\text { sampling time was divided between } \\
\text { the mesohabitats present }\end{array}$ & $\begin{array}{l}\text { Species, except } \\
\text { Diptera, } \\
\text { Oligochaeta, } \\
\text { Hydrachnidiae and } \\
\text { Collembola }\end{array}$ & $\begin{array}{l}\text { Hill et al. } \\
\text { (2015) }\end{array}$ \\
\hline 2 & $\begin{array}{l}\text { Huddersfield, } \\
\text { West } \\
\text { Yorkshire, } \\
\text { UK n }=20\end{array}$ & $\sim 68 \mathrm{Km}^{2}$ & 162,949 & $\begin{array}{l}\text { Ponds were sampled following the } \\
\text { guidelines of the National Pond } \\
\text { Survey, during the spring and } \\
\text { autumn seasons. Soft benthic } \\
\text { samples were also collected }\end{array}$ & $\begin{array}{l}\text { Species, except } \\
\text { Ostracoda, } \\
\text { Copepoda and } \\
\text { Diptera }\end{array}$ & $\begin{array}{l}\text { Wood } \\
\text { et al. } \\
(2001)\end{array}$ \\
\hline 3 & $\begin{array}{l}\text { Birmingham } \\
\text { and the Black } \\
\text { Country, UK } \\
\mathrm{n}=30\end{array}$ & $\begin{array}{r}\sim 599 \\
\mathrm{Km}^{2}\end{array}$ & $1,111,300$ & $\begin{array}{l}\text { Ponds were sampled following the } \\
\text { guidelines of the National Pond } \\
\text { Survey, during the spring and } \\
\text { summer seasons. }\end{array}$ & $\begin{array}{l}\text { Species, except } \\
\text { Diptera, } \\
\text { Sphaeriidae and } \\
\text { Oligochaeta }\end{array}$ & $\begin{array}{c}\text { Thornhill } \\
\text { (2013) }\end{array}$ \\
\hline 4 & $\begin{array}{l}\text { Halton, UK } \\
\mathrm{n}=25\end{array}$ & $\sim 91 \mathrm{Km}^{2}$ & 125,746 & $\begin{array}{l}\text { Individual ponds were sampled in the } \\
\text { summer and autumn seasons for } \\
2 \text { years. Samples were collected } \\
\text { from all identified mesohabitats } \\
\text { until no new species were recorded }\end{array}$ & Species & $\begin{array}{l}\text { Gledhill } \\
\text { et al. } \\
(2008)\end{array}$ \\
\hline 5 & $\begin{array}{l}\text { Stockport, UK } \\
\mathrm{n}=16\end{array}$ & $\begin{array}{r}\sim 122 \\
\mathrm{Km}^{2}\end{array}$ & 24,497 & $\begin{array}{l}\text { Samples were collected in the } \\
\text { summer season from all identified } \\
\text { mesohabitats until no new species } \\
\text { were recorded }\end{array}$ & $\begin{array}{l}\text { Species except } \\
\text { Diptera, and } \\
\text { Oligochaeta which } \\
\text { were not } \\
\text { examined }\end{array}$ & $\begin{array}{l}\text { Pond life } \\
\text { Project } \\
(2000)\end{array}$ \\
\hline
\end{tabular}

macroinvertebrate species in all available microhabitats until no new species were recorded. However, macroinvertebrate richness recorded from the two sampling strategies has been shown to be comparable (see Hill et al. 2017a). Preliminary analysis in this study showed no significant difference in macroinvertebrate diversity between sites that were sampled for $3 \mathrm{~min}$ or sampled exhaustively (Mann-Whitney, $\mathrm{W}=1812$, $\mathrm{p}$ value $=0.7943$ ). In addition, there was no significant difference in diversity between sampling across multiple seasons or only the summer season (Mann-Whitney, $\mathrm{W}=912$, $\mathrm{p}$ value $=0.9139$ ). Ponds were designated as urban based on their location within 'developed land use areas' (DLUA). DLUAs are used by the UK Ordnance Survey to delineate urban and non-urban land cover (see Hill et al. 2017a supplementary material for a discussion on the definition of an urban pond). The urban ponds examined in this study were located in a range of urban settlements, from a large, densely populated city (e.g., Birmingham) to smaller towns (e.g., Stockport) and included ponds in domestic gardens and urban parks, industrial ponds and ponds principally designed to facilitate drainage (e.g., stormwater ponds). Across the five studies, the majority of macroinvertebrates were identified to species level, however Diptera were recorded to family level and Oligochaeta, Sphaeriidae, Collembola and Hydrachnidiae were recorded as such. The data provided by the five contributing studies was converted into a presence-absence matrix to reduce any sampling bias and ensure the studies were comparable. 
Fig. 1 Location of the 132 surveyed urban ponds ( 25 in Halton, 41 in

Loughborough, 16 in

Stockport, 30 in

Birmingham and 20 in

Huddersfield) across

England

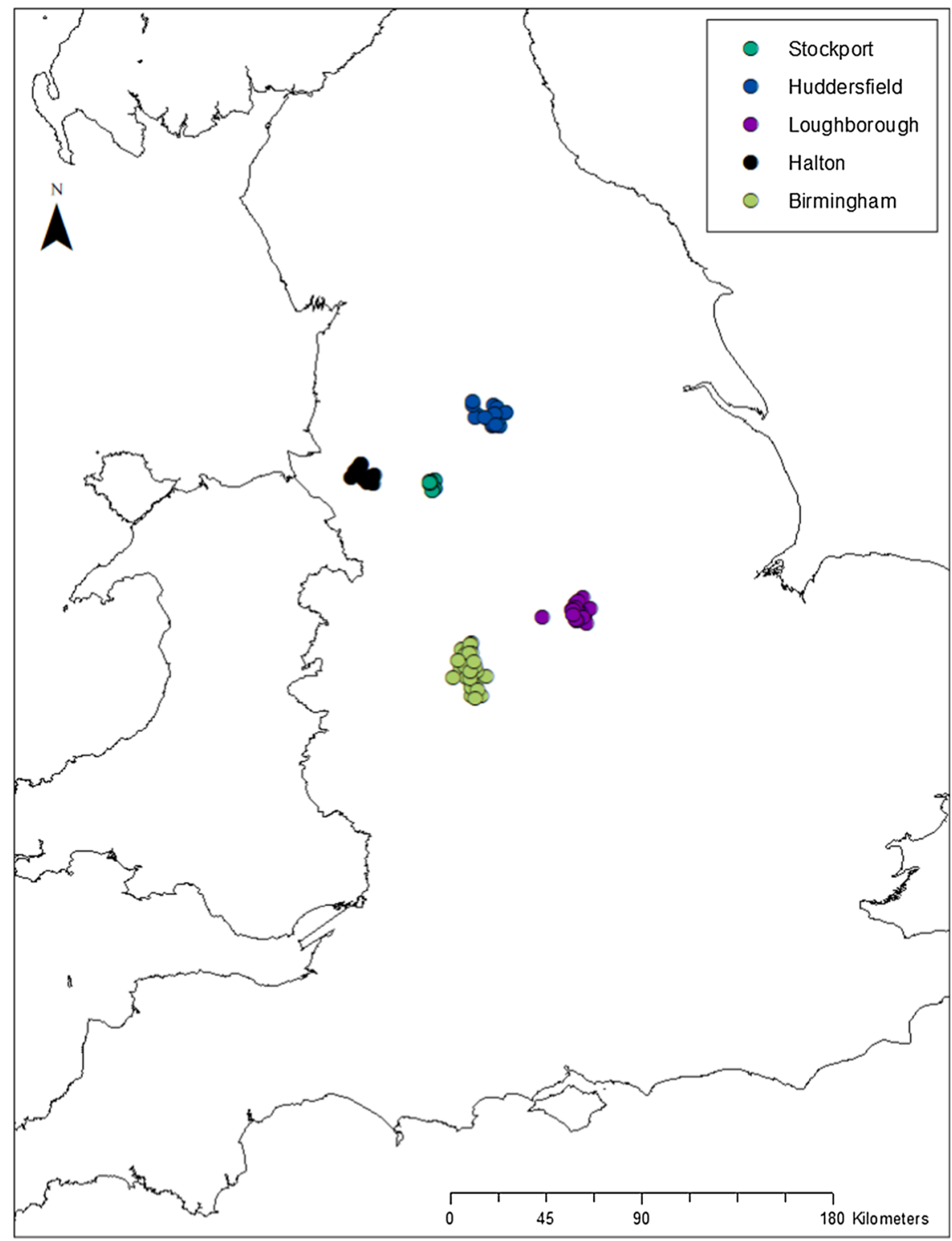

Statistical analysis

\section{Alpha and gamma diversity}

All statistical analysis was conducted in R (R Development Core Team 2013). Alpha diversity is defined here as the diversity within an individual sample site (pond) whilst gamma diversity refers to the overall diversity of a given settlement. The Chao 2 estimator (in the vegan package in R: Oksanen et al. 2017) was used to calculate estimated gamma diversity for the different urban settlements. Differences between estimated gamma diversity for the urban settlements were considered significant if the $95 \%$ confidence intervals (CI) did not overlap. Differences in macroinvertebrate diversity (alpha diversity) and environmental conditions among urban ponds from the five urban settlements were examined using a Kruskal-Wallis test. Pairwise comparisons using Nemenyi post hoc tests (in the PMCMR package in R: Pohlert 2016) were undertaken to determine where significant differences among the five urban settlements occurred. Kruskal-Wallis tests with Nemenyi post hoc tests 
were also used to test for differences in environmental characteristics among the five urban settlements.

\section{Beta diversity}

Beta-diversity is defined here as the spatial distribution and variation of communities between sample sites within a selected area (Socolar et al. 2016). NonMetric Multidimensional Scaling (NMDS; using the metaMDS function in $\mathrm{R}$ ) was used to visualise the variability in macroinvertebrate community composition and environmental conditions within and among urban settlements. Heterogeneity in community composition and environmental parameters among the five urban settlements was statistically analysed using a permutational multivariate analysis of variance (PerMANOVA) and pairwise comparisons were calculated (Pedro Martinez Arbizu pers comm). To examine the heterogeneity of pond macroinvertebrate compositions and environmental parameters within the urban settlement groups (Halton, Loughborough, Huddersfield, Birmingham and Stockport) homogeneity of multivariate dispersions were calculated using the betadisper function in vegan and comparisons were statistically tested using an ANOVA. Pairwise Tukey's HSD tests were used to determine where significant differences in multivariate dispersion among the urban settlements occurred. For NMDS, assessment of homogeneity of dispersion and PerMANOVA analyses, the Sorensen dissimilarity measure was used for macroinvertebrate data and Euclidean distance for environmental conditions. The percentage of pond shaded and $\mathrm{pH}$ were removed from these analyses as the percentage pond shading was not recorded from study 2 and $\mathrm{pH}$ was not recorded from study 5. Partial Mantel tests (based on the Pearson correlation coefficient and 999 random permutations) were used to examine the relationships between biological dissimilarity (based on the Bray-Curtis dissimilarity) and spatial distance within and among urban settlements using the function mantel.partial in the vegan package. Partial Mantel tests examine the relationship between two pairwise matrices (in this case the biological dissimilarity and geographic distance) while holding a third pairwise matrix (Euclidian environmental dissimilarity) constant (Wright et al. 2016). The weighted mean location (centroids of the locations of the ponds within each settlement) was used to determine spatial distance between each urban settlement. Indicator value analysis (Dufrêne and Legendre 1997) was undertaken using the function multipatt in the indicspecies package (De Caceres and Jansen 2016) to assess which taxa were characteristic of the five urban settlements. To examine the processes driving community heterogeneity within ponds in each urban settlement and for all ponds across the study region, beta-diversity (calculated here using the Sørensen dissimilarity metric) was partitioned into nestedness and species turnover using the function beta.sample from the package betapart (Baselga et al. 2017) in R. The function beta.sample randomly resamples the three multiple-site dissimilarities (total beta-diversity, nestedness and turnover) for a chosen subset of sites of the original dataset (Baselga et al. 2017). The urban group with the lowest number of sites in the dataset in this study was Stockport (16 ponds) and as a result 16 ponds were randomly sampled 100 times from each of the other 4 urban groups and for all ponds to facilitate a direct comparison among the urban pond groups. The relative contribution to total macroinvertebrate diversity from three hierarchical levels of spatial scale was calculated using additive partitioning of taxonomic richness. The data was organised according to the following hierarchical structure: diversity among all individual ponds, among ponds within the urban settlements and among urban settlements within England. As a result, the diversity model examined in this study was: $\gamma=\alpha+\beta 1+\beta 2(\gamma$ refers to the total macroinvertebrate diversity (gamma diversity), $\alpha$ reflects the average diversity among all ponds (alpha diversity), and $\beta 1$ refers to the compositional variation in communities between ponds within individual urban settlements and $\beta 2$ refers to the compositional variation in communities among urban settlements within England). The observed diversity of each component $(\alpha, \beta 1$ and $\beta 2$ ) was compared with a null model of expected diversity, generated by individual-based randomisations, to test the significance of observed patterns of diversity (Crist et al. 2003). The p-values calculated by this procedure indicate the significance of departure (greater or less) in the observed values from the expected values. Additive partitioning of taxonomic richness was undertaken using the function adipart in the vegan package. 


\section{Results}

Environmental characteristics

Significant differences in altitude (Kruskal-Wallis test df $\left.=4, \chi^{2}=95.419, \mathrm{p}<0.01\right)$, pH (Kruskal-Wallis test $\left.\mathrm{df}=4, \chi^{2}=36.905, \mathrm{p}<0.01\right)$, percentage emergent macrophytes (Kruskal-Wallis test $\mathrm{df}=4$, $\chi^{2}=19.902, \mathrm{p}<0.01$ ), pond area (Kruskal-Wallis test $\left.\mathrm{df}=4, \chi^{2}=57.081, \mathrm{p}<0.01\right)$ and percentage shading (Kruskal-Wallis test $\mathrm{df}=4, \chi^{2}=15.946$, $\mathrm{p}<0.01$ ) were recorded among the five (5) urban settlements (Table 2). Pair-wise Nemenyi post hoc tests indicated; (1) ponds in Halton and Loughborough were at a significantly $(\mathrm{p}<0.01)$ lower altitude than urban ponds in Birmingham, Huddersfield and Stockport, (2) pH was significantly $(\mathrm{p}<0.01)$ lower among ponds in Huddersfield compared to ponds from Halton, Loughborough and Birmingham, (3) ponds in Birmingham had a significantly $(\mathrm{p}<0.05)$ lower macrophyte coverage than ponds from Halton and Stockport, and macrophyte coverage was significantly $(\mathrm{p}<0.05)$ higher among ponds from Stockport than Loughborough, (4) ponds in Halton and Loughborough were significantly $(\mathrm{p}<0.05)$ smaller than ponds in Birmingham and Huddersfield and (5) ponds were significantly $(\mathrm{p}<0.05)$ less shaded from Loughborough than Halton and Birmingham (Table 2: Table 3).

Alpha and gamma diversity

A total of 337 macroinvertebrate taxa were recorded across the five urban pond groups: Halton (108 taxa), Loughborough (170 taxa), Stockport (140 taxa), Birmingham (193 taxa) and Huddersfield (100 taxa) (Table 4). Estimated gamma diversity (based on the Chao 2 estimator) was significantly $(\mathrm{p}<0.05)$ higher in Loughborough (estimated gamma: 243.7 CI 190.4-297.2) and Birmingham ponds (estimated gamma: 217.5 CI 196.8-238.2) than urban ponds in Halton (estimated gamma: 131.1 CI 107.1-155). Estimated gamma diversity from urban ponds in Stockport (estimated gamma: 185.1 CI 151.9-218.2) and Huddersfield (estimated gamma: 199 CI

Table 2 Summary table of environmental characteristics for urban ponds in the 5 urban settlements. EM: emergent macrophytes

\begin{tabular}{|c|c|c|c|c|c|c|}
\hline & & Area $\left(\mathrm{M}^{2)}\right.$ & EM (\%) & $\mathrm{pH}$ & Shading (\%) & $\begin{array}{l}\text { Altitude } \\
\text { (Masl) }\end{array}$ \\
\hline \multirow[t]{4}{*}{ Loughborough $(\mathrm{N}=41)$} & Mean & 780.3 & 23 & 7.8 & 17.5 & 59.1 \\
\hline & Standard error & 301.3 & 4.6 & 0.1 & 4.5 & 3.9 \\
\hline & Median & 21.2 & 10 & 7.7 & 2 & 49 \\
\hline & Range & $1-9309$ & $0-100$ & $6.3-9.8$ & $0-100$ & $35-138$ \\
\hline \multirow[t]{4}{*}{ Huddersfield ( $\mathrm{N}=20$ ) } & Mean & 3121.3 & 24.5 & 6.8 & $\mathrm{n} / \mathrm{a}$ & 153.5 \\
\hline & Standard error & 1043.1 & 4.1 & 0.1 & $\mathrm{n} / \mathrm{a}$ & 11.3 \\
\hline & Median & 1400 & 17.5 & 7 & $\mathrm{n} / \mathrm{a}$ & 170 \\
\hline & Range & $50-16,000$ & $0-60$ & $5.2-7.7$ & $\mathrm{n} / \mathrm{a}$ & $65-230$ \\
\hline \multirow[t]{4}{*}{ Birmingham $(\mathrm{N}=30)$} & Mean & 3597.1 & 12.62 & 7.7 & 30.1 & 138.8 \\
\hline & Standard error & 739.9 & 2.4 & 0.1 & 5.7 & 2.8 \\
\hline & Median & 1798 & 8.6 & 7.6 & 17.9 & 140.5 \\
\hline & Range & $299-14,967$ & $0-41$ & $6.7-9.1$ & $0-100$ & $93-164$ \\
\hline \multirow[t]{4}{*}{ Halton $(\mathrm{N}=21)$} & Mean & 324.6 & 27.1 & 7.7 & 30.9 & 37.6 \\
\hline & Standard error & 37.2 & 3.6 & 0.1 & 4.7 & 3.8 \\
\hline & Median & 300 & 25 & 7.7 & 30 & 36.3 \\
\hline & Range & $33.5-826.2$ & $2-75$ & $6.8-8.2$ & $2-90$ & $6.7-69.2$ \\
\hline \multirow[t]{4}{*}{ Stockport $(\mathrm{N}=16)$} & Mean & 895.9 & 57.8 & $\mathrm{n} / \mathrm{a}$ & 14.4 & 97.2 \\
\hline & Standard error & 156.5 & 10.4 & $\mathrm{n} / \mathrm{a}$ & 5.6 & 8.2 \\
\hline & Median & 758.7 & 72.5 & $\mathrm{n} / \mathrm{a}$ & 10 & 80 \\
\hline & Range & $88-2123.2$ & $1-100$ & $\mathrm{n} / \mathrm{a}$ & $0-85$ & $65-155$ \\
\hline
\end{tabular}


Table 3 Post hoc Tukey pairwise tests of (a) altitude, (b) pH, (c) pond shading, (d) area, and (e) emergent macrophytes between the five urban settlements; Loughborough, Huddersfield, Birmingham, Halton and Stockport

\begin{tabular}{|c|c|c|c|c|c|}
\hline (a) Altitude & & & & & \\
\hline & Loughborough & Huddersfield & Birmingham & Halton & Stockport \\
\hline \multicolumn{6}{|l|}{ Loughborough } \\
\hline Huddersfield & $\wedge$ & & \multicolumn{3}{|c|}{$\wedge$} \\
\hline Birmingham & \multicolumn{2}{|l|}{$\wedge$} & \multicolumn{3}{|c|}{$\wedge$} \\
\hline Halton & \multirow{2}{*}{\multicolumn{2}{|c|}{$\wedge$}} & & & \\
\hline Stockport & & & \multicolumn{3}{|c|}{$\wedge$} \\
\hline \multicolumn{6}{|l|}{ (b) $p H$} \\
\hline Loughborough & Loughborough & $\begin{array}{c}\text { Huddersfield } \\
\wedge\end{array}$ & \multirow[t]{5}{*}{ Birmingham } & \multirow[t]{5}{*}{ Halton } & \multirow[t]{5}{*}{ Stockport } \\
\hline Huddersfield & & & & & \\
\hline Birmingham & & $\wedge$ & & & \\
\hline Halton & & $\wedge$ & & & \\
\hline \multirow{2}{*}{\multicolumn{6}{|c|}{ (c) Pond shading }} \\
\hline & & & & & \\
\hline & Loughborough & Huddersfield & Birmingham & Halton & Stockport \\
\hline \multicolumn{6}{|l|}{ Loughborough } \\
\hline \multicolumn{6}{|l|}{ Huddersfield } \\
\hline Birmingham & \multicolumn{5}{|l|}{$\wedge$} \\
\hline Halton & \multicolumn{5}{|l|}{$\wedge$} \\
\hline \multicolumn{6}{|l|}{ Stockport } \\
\hline \multicolumn{6}{|l|}{ (d) Area } \\
\hline & Loughborough & Huddersfield & Birmingham & Halton & Stockport \\
\hline \multicolumn{6}{|l|}{ Loughborough } \\
\hline Huddersfield & $\wedge$ & & & \multicolumn{2}{|l|}{$\wedge$} \\
\hline Birmingham & $\wedge$ & & & $\wedge$ & \\
\hline \multicolumn{6}{|l|}{ Halton } \\
\hline Stockport & \multicolumn{5}{|l|}{$\wedge$} \\
\hline \multicolumn{6}{|l|}{$\begin{array}{l}\text { (a) Emergent } \\
\text { macrophytes }\end{array}$} \\
\hline & Loughborough & Huddersfield & Birmingham & Halton & Stockport \\
\hline \multicolumn{6}{|l|}{ Loughborough } \\
\hline \multicolumn{6}{|l|}{ Huddersfield } \\
\hline \multicolumn{6}{|l|}{ Birmingham } \\
\hline Halton & & & $\wedge$ & & \\
\hline Stockport & $\wedge$ & & $\wedge$ & & \\
\hline
\end{tabular}

^Indicates that the environmental variable was significantly greater in the urban settlement in the table column than the table row

118.2-279.7) was not statistically different from the other urban centres. Significant differences (KruskalWallis test $\left.\mathrm{df}=4, \chi^{2}=34.812, \mathrm{p}<0.01\right)$ in alpha diversity were recorded among the 5 urban settlements
(Table 4; Fig. 2). Results from the Nemenyi post hoc test indicated that ponds in Birmingham (mean: 44.6 median: 44.5) had significantly higher alpha diversity than ponds in Halton (mean: 24.6 median: 28), 
Table 4 Summary table of macroinvertebrate diversity recorded from urban ponds in Halton, Loughborough, Stockport, Birmingham and Huddersfield and from all ponds combined

\begin{tabular}{|c|c|c|c|c|c|c|}
\hline & Loughborough & Huddersfield & Birmingham & Halton & Stockport & $\begin{array}{l}\text { All } \\
\text { cities }\end{array}$ \\
\hline $\begin{array}{r}\text { Estimated } \\
\text { richness }\end{array}$ & 243.7 & 199 & 217.5 & 131.1 & 185.1 & 418.1 \\
\hline $\begin{array}{l}\text { Total } \\
\text { richness }\end{array}$ & 170 & 100 & 193 & 108 & 140 & 338 \\
\hline Mean & 22.3 & 15.6 & 46.5 & 24.6 & 26.7 & 27.7 \\
\hline SE & 2.7 & 1.4 & 3.7 & 2.4 & 4.2 & 1.7 \\
\hline Median & 15 & 15 & 44.5 & 28 & 20.5 & 21.5 \\
\hline Min & 2 & 6 & 14 & 6 & 10 & 2 \\
\hline Max & 61 & 27 & 87 & 43 & 61 & 87 \\
\hline $\begin{array}{c}\text { Unique } \\
\text { Taxa }\end{array}$ & $\begin{array}{l}\text { 11 Coleoptera, } 3 \\
\text { Gastropoda, } 11 \\
\text { Trichoptera, } 1 \\
\text { Ephemeroptera, 1 } \\
\text { Arhynchobdellida, } \\
2 \text { Diptera, 1 } \\
\text { Collembola }\end{array}$ & $\begin{array}{l}9 \text { Coleoptera, } 2 \\
\text { Gastropoda, } 1 \text { Bivalvia, } \\
1 \text { Hemiptera, } 7 \\
\text { Veneroida, } 7 \\
\text { Trichoptera, } 2 \\
\text { Ephemeroptera, } 2 \\
\text { Plecoptera, 1 } \\
\text { Megaloptera, } 1 \\
\text { Neuroptera }\end{array}$ & $\begin{array}{l}9 \text { Coleoptera, } 2 \\
\text { Gastropoda, } 10 \\
\text { Hemiptera, } 4 \\
\text { Trichoptera, } 1 \\
\text { Ephemeroptera, } 1 \\
\text { Arhynchobdellida, } 2 \\
\text { Odonata, } 4 \text { Seriata, } 4 \\
\text { Diptera, } 1 \text { Amphipoda }\end{array}$ & $\begin{array}{l}7 \text { Coleoptera, } \\
1 \\
\text { Gastropoda }\end{array}$ & $\begin{array}{l}20 \\
\text { Coleoptera, } \\
1 \\
\text { Gastropoda, } \\
2 \\
\text { Hemiptera, } \\
1 \text { Odonata, } \\
1 \text { Seriata }\end{array}$ & \\
\hline
\end{tabular}

Loughborough (mean: 22.3 median: 15), Stockport (mean: 26.7 median: 20.5) and Huddersfield (mean: 15.6 median: 15) (Fig. 2).

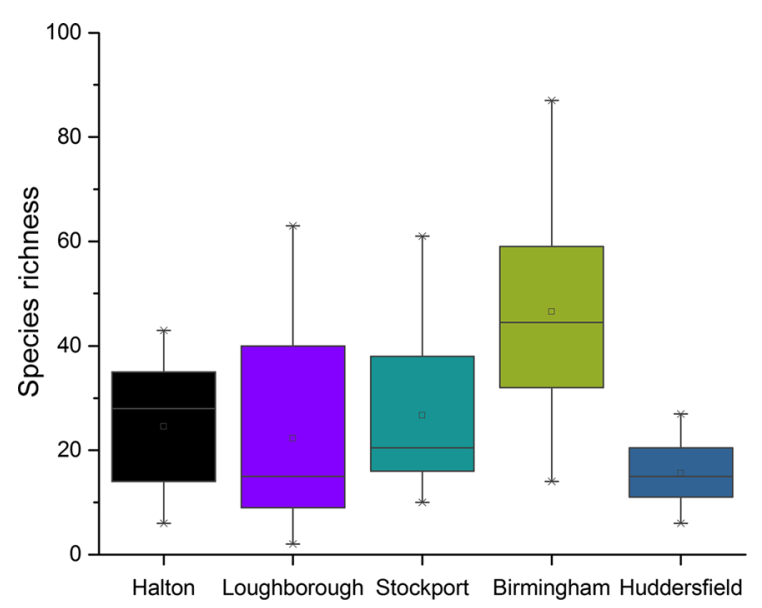

Fig. 2 Median macroinvertebrate richness of macroinvertebrates recorded from urban ponds in Halton, Loughborough, Stockport, Birmingham and Huddersfield. Boxes show 25th, 50th, and 75th percentiles and whiskers show 5th and 95th percentiles
Beta-diversity

PerMANOVA tests found environmental characteristics to be significantly different between ponds in Halton and Stockport, Birmingham and Huddersfield (p $<0.05$; Fig. 3a; see Supplementary Material Table $\mathrm{S} 1$ for all pairwise PerMANOVA $R$ and $\mathrm{p}$ values). In addition, environmental conditions were recorded to be significantly different between ponds in Loughborough and Birmingham $(\mathrm{p}<0.05)$. Pairwise comparisons of multivariate dispersion for environmental parameters found dispersion to be significantly higher in ponds in Birmingham (median distance: 2538) and Huddersfield (median distance: 2520) than Halton (median distance: 137; $\mathrm{p}<0.05$, Fig. 3c). Ponds in Birmingham also had significantly higher dispersion compared to Loughborough (median distance: $446 ; \mathrm{p}<0.05$; see Supplementary Material Table S2 for full pairwise results).

A clear distinction among aquatic macroinvertebrate assemblages in ponds in Stockport, Halton and Birmingham was observed within the NMDS ordination, but macroinvertebrate communities among ponds in Loughborough and Huddersfield overlapped in the NMDS biplot (Fig. 3b). PerMANOVA pairwise 
Fig. 3 Non-metric multidimensional scaling plots of dissimilarity in (a) environmental conditions (Euclidean distance) and $\mathbf{b}$ aquatic macroinvertebrate communities (Sørenson dissimilarity) from urban ponds in the $5 \mathrm{UK}$ urban settlements and boxplots of multivariate dispersion distances for c environmental conditions and $\mathbf{d}$ urban pond macroinvertebrate communities from the $5 \mathrm{UK}$ urban settlements
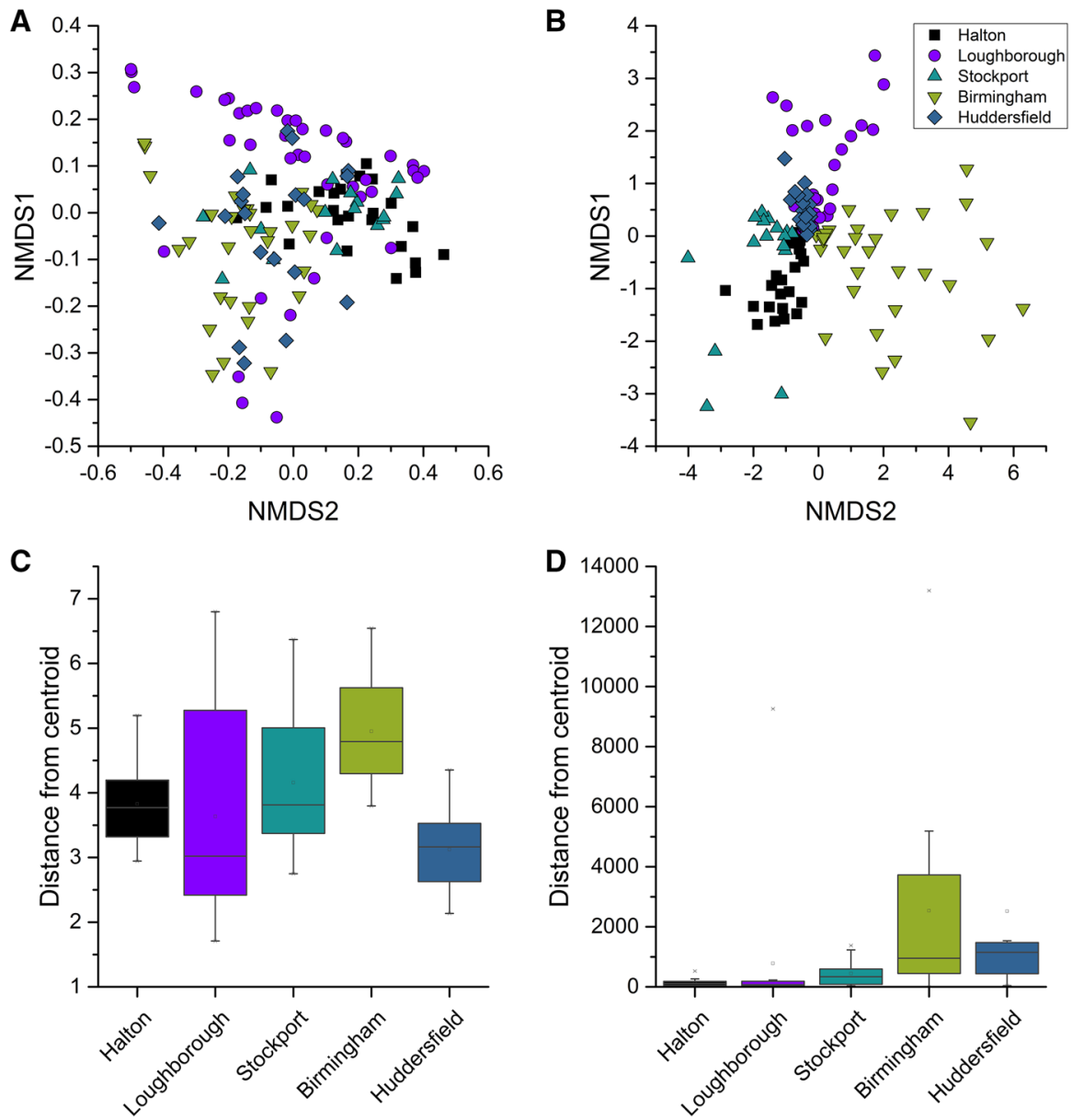

tests found macroinvertebrate communities among the five urban settlements to be significantly different to each other $(\mathrm{p}<0.01$; see Supplementary Material Table S3 for pairwise PerMANOVA $R$ and $\mathrm{p}$ values). Significant differences in multivariate dispersions (ANOVA $\mathrm{df}=4, \quad \mathrm{~F}=5.521, \quad \mathrm{p}<0.01$ ) were recorded among the 5 urban settlements (Fig. 3d). Multivariate dispersion was significantly lower among macroinvertebrate assemblages in Birmingham (average median distance to group centroid: 0.39) than pond assemblages in Loughborough (average median distance to group centroid: $0.49 ; \mathrm{p}<0.01$ ), Stockport (average median distance to group centroid: 0.52 ; $\mathrm{p}<0.01$ ) and Huddersfield (average median distance to group centroid: $0.47 ; \mathrm{p}<0.05$, Fig. $3 \mathrm{~d}$ ). No significant difference was recorded in multivariate dispersion among communities in Halton (average median distance to group centroid: 0.46 ) compared to the other urban settlements, although macroinvertebrate communities from Halton demonstrated a much greater range of multivariate dispersions (Fig. 3d). No significant correlation was recorded between macroinvertebrate community dissimilarity (Bray-Curtis) and spatial distance of ponds within Loughborough (Mantel $\mathrm{r}=0.03, \mathrm{p}=0.31$ ), Birmingham (Mantel $\mathrm{r}=0.11, \mathrm{p}=0.08$ ) and Huddersfield (Mantel $\mathrm{r}=-0.17, \mathrm{p}=0.97$ ), although a significant weak positive correlation was recorded in Halton (Mantel $\mathrm{r}=0.14, \mathrm{p}<0.02$ ) and moderate positive correlation in Stockport (Mantel $r=0.48$, $\mathrm{p}<0.01)$. In addition, Mantel tests showed that there was no significant correlation between macroinvertebrate community dissimilarity and spatial distance (weighted mean location) between urban settlements (Mantel $\mathrm{r}=0.19, \mathrm{p}=0.33$ ).

A total of 8 taxa were recorded only from ponds in Halton, 30 in Loughborough, 25 in Stockport, 38 in Birmingham and 33 in Huddersfield amounting to 
$40 \%$ of all macroinvertebrate taxa recorded in this study (134 taxa, Table 4). A total of 7 macroinvertebrate taxa were identified as indicator taxa (using Indicator Value Analysis) for ponds in Halton, 4 were statistically associated with ponds in Loughborough, 26 taxa were associated with ponds in Stockport, 46 taxa were identified as indicator taxa for ponds in Birmingham and 10 taxa were identified as indicator taxa for ponds in Huddersfield. The top five macroinvertebrate taxa identified as indicator species for urban ponds in the five UK urban settlements are presented in Table 5 (see Supplementary Material Table S4 for the full list of statistically significant indicator taxa).

Aquatic macroinvertebrate communities demonstrated high levels of beta-diversity within ponds in each of the 5 urban settlements based on the Sørensen dissimilarity metric (Halton: 0.86, Loughborough: 0.89, Stockport: 0.89, Birmingham: 0.84 and Huddersfield: 0.89) and when all ponds in the study area were considered ( 0.90 ; Fig. 4). Almost all of the variation in macroinvertebrate composition was explained by species turnover, rather than nestedness for communities in Halton (species turnover: $90.1 \%$, nestedness: 9.9\%), Loughborough (species turnover: $83.5 \%$, nestedness: $16.5 \%$ ), Stockport (species turnover: $91.5 \%$, nestedness: $8.5 \%$ ), Birmingham (species turnover: $88.3 \%$, nestedness: $11.7 \%$ ), and Huddersfield (species turnover: $94.7 \%$, nestedness: $5.3 \%$ ) and when all ponds were considered (species turnover: 91.0\%, nestedness: 9.0\%; Fig. 4). Additive partitioning of diversity showed that alpha diversity was significantly lower than that expected under the null model

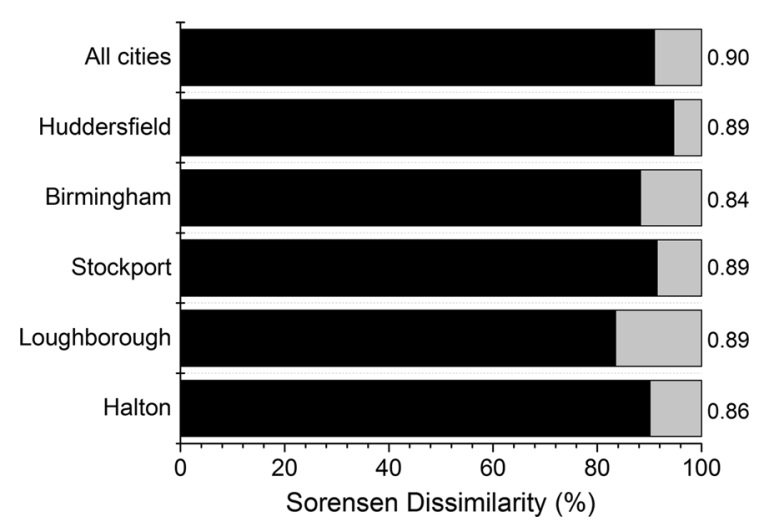

Fig. 4 Relative contribution of species turnover and nestedness to total community dissimilarity within urban ponds in Halton, Loughborough, Stockport, Birmingham and Huddersfield

( $\mathrm{p}=0.001$ ) despite contributing $42 \%$ to gamma (total) diversity (Fig. 5). Similarly, compositional variation within cities ( $\beta 1$ : contributed $34 \%$ to gamma diversity) was significantly lower than expected by chance ( $p<0.001)$. However, the contribution to total diversity by $\beta 2$ (the compositional variation in macroinvertebrate communities among urban settlements; 24\%) was significantly greater $(\mathrm{p}<0.001)$ than that expected under the null model (Fig. 5).

\section{Discussion}

We demonstrate significant differences in aquatic macroinvertebrate community composition within and among urban settlements. This suggests that ponds do

Table 5 Top 5 macroinvertebrate taxa identified as indicator species for urban ponds in the 5 UK urban settlements (see supplementary material Table S3 for the full list of statistically significant species indicator values)

\begin{tabular}{|c|c|c|c|c|c|c|c|c|c|}
\hline Loughborough & Stat & Huddersfield & Stat & Birmingham & Stat & Halton & Stat & Stockport & Stat \\
\hline Planaridae sp. & 0.56 & $\begin{array}{l}\text { Leptophlebia } \\
\text { marginata }\end{array}$ & 0.55 & Sphaeriium spp. & 0.85 & $\begin{array}{c}\text { Anacaena } \\
\text { limbata }\end{array}$ & 0.70 & $\begin{array}{l}\text { Hydroporus } \\
\text { planus }\end{array}$ & 0.68 \\
\hline Physa acuta & 0.52 & Nemurella picteti & 0.50 & Corixidae Nymph & 0.78 & Nepa cinerea & 0.58 & $\begin{array}{l}\text { Hydroporus } \\
\text { memnonius }\end{array}$ & 0.61 \\
\hline $\begin{array}{l}\text { Zonitoides } \\
\text { nitidus }\end{array}$ & 0.38 & Tinodes waeneri & 0.50 & $\begin{array}{l}\text { Zygoptera instar I } \\
\quad \text { \& II }\end{array}$ & 0.75 & Scirtdae larvae & 0.51 & $\begin{array}{l}\text { Limnephilus } \\
\text { vittatus }\end{array}$ & 0.59 \\
\hline \multirow[t]{2}{*}{$\begin{array}{l}\text { Hydrophilidae } \\
\text { larvae }\end{array}$} & 0.31 & Agrypnia obsoleta & 0.45 & Dugesia tigrina & 0.73 & $\begin{array}{l}\text { Anisus } \\
\quad \text { leucostoma }\end{array}$ & 0.42 & $\begin{array}{l}\text { Hydroporus } \\
\text { gyllenhalii }\end{array}$ & 0.56 \\
\hline & & Pisidium indet & 0.45 & $\begin{array}{l}\text { Hydrometra } \\
\text { Nymph }\end{array}$ & 0.71 & $\begin{array}{l}\text { Laccobius } \\
\quad \text { bipunctatus }\end{array}$ & 0.40 & $\begin{array}{l}\text { Hydroporus } \\
\text { nigrita }\end{array}$ & 0.56 \\
\hline
\end{tabular}

All $p<0.01$ 


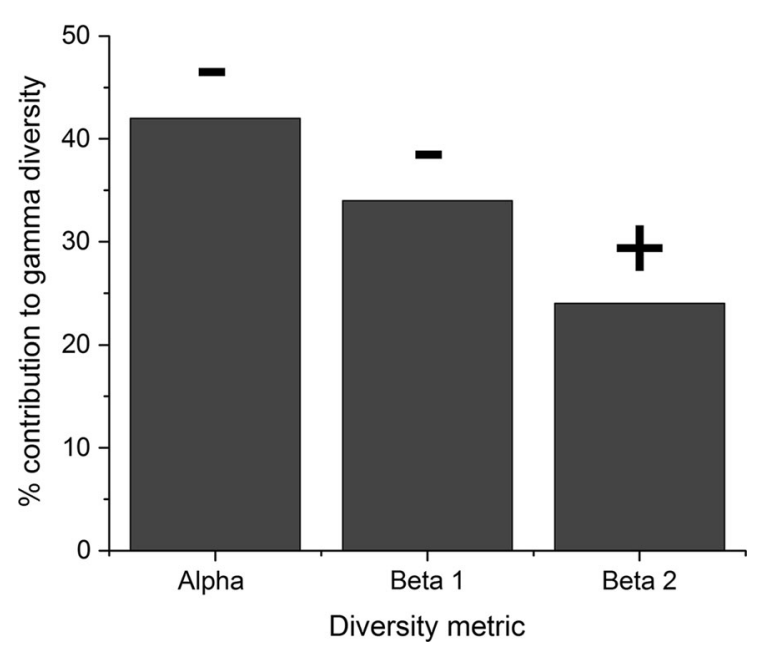

Fig. 5 Relative contribution of alpha diversity $(\alpha)$ and beta diversity ( $\beta 1$ among sites within urban settlements, $\beta 2$ among urban settlements within the study area) to gamma diversity (total aquatic macroinvertebrate richness among urban ponds). Observed results were compared to expected results using individual based randomizations (+ significantly larger, - significantly smaller)

not follow the same ecological response to urbanisation as terrestrial and lotic habitats (biotic homogenization) but support highly heterogeneous macroinvertebrate communities. The high beta-diversity of macroinvertebrate communities within urban settlements could almost entirely be attributed to species turnover (species replacement from one pond to another) across all urban settlements, indicating that it was the variation in community composition (species replacement from one site to another) rather than differences in taxonomic richness (species poor communities being subsets of species rich communities) that was driving the heterogeneity in community assemblage (Viana et al. 2016). The high contribution of species turnover to beta-diversity within urban ponds in individual urban settlements most likely reflects the wide variety of anthropogenic uses of urban ponds (e.g., stormwater retention, aesthetics, sediment collection and biodiversity) and the different management practices which they are subject to. The small catchment areas of ponds (Williams et al. 2003) and the different management practices promotes a wide range of successional stages and environmental conditions across urban areas for macroinvertebrate taxa to utilise (Hill et al. 2015; Thornhill et al. 2017a). Previous studies have demonstrated that variation in local environmental conditions are often the principle regulator of species turnover in pond systems as macroinvertebrate taxa are essentially filtered by environmental gradients (Cottenie 2005; Hill et al. 2017b). Compositional differences driven by species turnover may also reflect the isolation of some ponds within urban settlements, which may increase the level of ecological uniqueness of urban ponds (Thornhill et al. 2017b; Fahrig 2003). Although ponds may exist in close spatial proximity, the structural complexity of urban landscapes (high-rise developments, walls and roads) may effectively isolate some ponds from other sites. Walls and buildings provide complex and impermeable vertical structures, and roads are a source of invertebrate mortality (from road traffic) as well as a physical barrier, which reduces the opportunity for successful dispersal and colonisation of macroinvertebrates. Complex structural mosaics may limit dispersal to such an extent that macroinvertebrate communities in some urban ponds may be separated from any species pool effect (spatial effects) on local communities (Heino et al. 2017). However, many urban ponds exist in networks, where they are linked through urban parks/nature reserves and blue/green corridors (Dallimer et al. 2012; Hassall 2014). Even where there is high spatial connectivity and dispersal rates, species turnover may still be high as the local variation in environmental conditions has been shown to be the dominant structuring process for pond communities (Cottenie 2005). Among small waterbodies, stochastic events such as priority effects (where the initial colonisation of one taxa at a site alters the biotic or abiotic condition of the site that positively or negatively effects later colonising taxa) and dispersal limitation often exerts a strong influence and may be contributing to the high community heterogeneity (taxonomic turnover) recorded (Scheffer et al. 2006).

Considerable differences in macroinvertebrate composition at an inter-city scale and the significantly greater contribution of broad scale beta components ( $\beta 2$ : the compositional variation in macroinvertebrate communities among the five UK urban settlements) to gamma diversity than expected by chance may be best explained by the effect of the developmental characteristics of an individual city and also betweensettlement isolation. Urban settlements develop in a variety of ways (reflecting local urban planning choices and historical context) such as low density, urban sprawl spread over a large spatial area (Terando 
et al. 2014) or as high density, compact landscapes ( $\mathrm{Ng}$ et al. 2012) with varying amounts of green/blue space (Dallimer et al. 2011). This is likely to affect the within-settlement environmental conditions, connectivity and the complexity of colonisation and dispersal pathways. This significant dissimilarity in community composition and high numbers of unique taxa at an inter-city scale may also reflect the ecological isolation between the five urban settlements. Urban areas can be disconnected from other nearby urban and nonurban landscapes (Laurenco et al. 2017) and as a result, there may be reduced colonisation to, or dispersal among, proximal and distant urban settlements, which may be driving the development of relatively unique faunal and floral communities recorded between urban settlements in this study. In addition, aquatic taxa that colonise isolated urban ponds may become trapped as they may be unable to navigate the complex dispersal routes in an urban landscape (Smith et al. 2009), or through the loss of aquatic stepping stones as a result of urban pond loss (Thornhill et al. 2017b). However, in the last few decades there has been significant improvement to freshwater quality in urban areas (Vaughan and Ormerod 2012), and the high beta diversity recorded among urban settlements may be the result of the sporadic recolonization of urban ponds from the proximal non-urban landscape as urban quality improves (Hill et al. 2017a).

\section{Alpha and gamma diversity}

In this study, significant differences were recorded among the urban settlements for both alpha and gamma diversity. The significantly higher alpha diversity in Birmingham compared to the other urban settlements is surprising considering that it is a highly developed, densely populated city, but may be explained by; (1) the significant amount of green space present in the city (Birmingham City Council 2013) increasing the colonisation and dispersal potential between ponds and; (2) by Birmingham City Council's recent efforts to improve water quality within the city (Birmingham City Council 2007). In addition, Birmingham displayed the highest alpha diversity but lowest beta-diversity, which may also be explained by the increased dispersal and colonisation potential reducing community heterogeneity. However, using average alpha diversity across a series of individual habitat patches to quantify biodiversity at a habitat network scale, such as an urban pondscape, may not be suitable and provide misleading information as alpha diversity operates at an individual scale and fails to acknowledge the complementarity of patches within habitat networks. Gamma diversity provides a useful measure to quantify large scale patterns of biodiversity although may not be an appropriate measure (if used individually) for aquatic management and conservation of ponds as it is unable to quantify how or where habitats contribute to gamma diversity (e.g. a few ponds with high species richness contributed most to gamma diversity or a large number of ponds across a given area contributed to gamma diversity). In contrast, beta-diversity approaches can provide more meaningful information about the spatial structure of habitat networks, and practical guidance for their management based on the relative importance and complementarity of the constituent patches. For example, beta-diversity can provide relevant information for the suitability of a 'single large' or 'several small' habitats for biodiversity conservation in a given area (Socolar et al. 2016).

\section{Conservation implications}

Quantifying spatial patterns and processes operating within ecological communities (beta-diversity) can provide more accurate and detailed information to identify the most suitable/efficient biodiversity management and conservation strategies (Socolar et al. 2016). Current pond conservation focuses on protecting individual sites of high biodiversity (Hassall et al. 2012), which is based on the assumption that macroinvertebrate communities among ponds demonstrate strong patterns of nestedness (conservation of the most species rich sites as other sites are nested subsets of these species rich sites). However, high beta-diversity among urban ponds in this study was dominated by species turnover (species replacement from one pond to another) rather than nestedness indicating that pond conservation practices (individual sites of high diversity) are not providing the most effective conservation of pond biodiversity. The dominance of species turnover suggests that conservation actions to enhance pond biodiversity would be most beneficial if undertaken at a landscape/network scale, conserving an array of complementary sites (incorporating the 'principle of complementarity'; Justus and Sarkar 
2002) with different species compositions (Hill et al. 2017b). Current pond conservation strategies need to be adapted in recognition of the fact that the greatest conservation value of ponds lies at the network scale reflecting the high contribution of species turnover to beta-diversity, in the heterogeneity of conditions among sites (promoting high community turnover and heterogeneity); and that conservation efforts should be focussed to ensure that pondscapes and heterogeneous environmental conditions at a landscape scale are maintained and where possible enhanced.

There has been a concerted effort to increase connectivity between fragmented natural habitat in urban landscapes, particularly for terrestrial habitats (Crook and Sanjayan 2006; LaPoint et al. 2015). There was some evidence of potential influence of connectivity in the fact that macroinvertebrate community dissimilarity within Halton and Stockport was significantly correlated to spatial distance between ponds, but this was inconsistent in the other areas sampled suggesting that such effects may be context specific. Among aquatic macroinvertebrate communities, increasing connectivity will increase the dispersal and colonisation potential for macroinvertebrate taxa but may also be detrimental to pond diversity, increasing the potential for the homogenisation of communities and the proliferation of non-native taxa and larger predators (particularly fish) in urban areas (Fahrig 2003; Scheffer et al. 2006). Combining high connectivity of some urban pond sites and moderate isolation for other ponds will promote aquatic diversity and maintain high community heterogeneity. At a local scale isolated ponds are less likely to support transient or sink species and could support specialist taxa that may be outcompeted in more highly connected sites (Scheffer et al. 2006).

Urban biodiversity conservation is currently primarily focussed upon terrestrial and lotic systems and small lentic pond habitats are almost entirely excluded from international conservation legislation (e.g. the Water Framework Directive and the Habitats Directive; EC 1992; EC 2000; Biggs et al. 2005; Hering et al. 2010). This study demonstrates that current conservation strategies are overlooking a key biodiversity resource in urban landscapes, which appears to be highly resilient to many of the effects of urbanisation and provides suitable habitats for colonisation and refuge for aquatic macroinvertebrate taxa (Hill et al. 2017a). Ponds may be easier and economically more effective to manage for biodiversity conservation than other waterbodies in urban areas (while simultaneously being able to provide key ecosystem services to citizens) as a result of; (1) the high frequency of ponds across urban landscapes; (2) the small catchment size of ponds (Davies et al. 2008a); (3) the significantly better water quality in ponds compared to flowing systems in urban areas (McGoff et al. 2016); (4) being a highly recognisable freshwater habitat suitable for citizens/volunteers to engage in urban freshwater conservation and management (Loiselle et al. 2017) and; (5) the high community and environmental heterogeneity of urban ponds, suitable for landscape-scale conservation measures.

\section{Conclusion}

This study has demonstrated that urban pond communities do not respond to urbanisation in the same way as lotic and terrestrial systems, supporting highly heterogeneous communities (high species turnover) within and among urban settlements. This is most likely the result of the wide range of environmental conditions present in an urban pondscape and the isolation of urban ponds at both a local scale (within urban settlements) and a regional scale (among urban settlements). High species turnover recorded in this study has demonstrated that urban pond biodiversity conservation would be most efficient at a pondscape scale (incorporating a wide range of pond sites). Pond conservation practices need to move away from a focus at an individual scale to conservation at a network scale to ensure the maximum possible diversity is being protected. Urban conservation planning must consider the organization of ecological communities in space to ensure the most accurate and detailed information is available for the development of freshwater conservation strategies.

Acknowledgements MJH gratefully acknowledges the support of Loughborough University Graduate School Studentship and is grateful to Barry Kenny, Danielle Ashdown and Richard Harland for assistance with field and laboratory work. Data from the Pond Life Project were collected under an EU LIFE Project grant, and Jonathan Guest and David Bentley carried out the surveys. Acknowledgements must be extended to Pedro Martinez Arbizu for providing $\mathrm{R}$ code to undertake pairwise PerMANOVA (please see: https://www.researchgate. 
net/post/How_can_I_do_PerMANOVA_pairwise_contrasts_ in_R).

Open Access This article is distributed under the terms of the Creative Commons Attribution 4.0 International License (http:// creativecommons.org/licenses/by/4.0/), which permits unrestricted use, distribution, and reproduction in any medium, provided you give appropriate credit to the original author(s) and the source, provide a link to the Creative Commons license, and indicate if changes were made.

\section{References}

Alberti M (2005) The effects of urban patterns on ecosystem function. Int Reg Sci Rev 28:168-192

Aronson MF, La Sorte FA, Nilon CH, Katti M, Goddard MA, Lepczyk CA, Warren PS, Williams NS, Cilliers S, Clarkson B, Dobbs C (2014) A global analysis of the impacts of urbanization on bird and plant diversity reveals key anthropogenic drivers. Proc R Soc B 281:20133330

Baselga A (2010) Partitioning the turnover and nestedness components of beta diversity. Glob Ecol Biogeogr 19:134-143

Baselga A, Orme D, Villeger S, De Bortoli J, Leprieur F (2017) Partitioning beta diversity into turnover and nestedness components. $\mathrm{R}$ package version 1.3. https://mran. microsoft.com/web/packages/betapart/betapart.pdf

Biggs J, Fox G, Whitfield M, Williams P (1998) A guide to the methods of the National Pond Survey. Pond Action, Oxford

Biggs J, von Fumetti S, Kelly-Quinn M (2017) The importance of small waterbodies for biodiversity and ecosystem services: implications for policy makers. Hydrobiologia 793:3-39

Biggs J, Williams P, Whitfield M, Nicolet P, Weatherby A (2005) 15 years of pond assessment in Britain: results and lessons learned from the work of Pond Conservation. Aquat Conserv Mar Freshw Ecosyst 15:693-714

Birmingham City Council (2007) The Birmingham plan: sustainable management of urban rivers and floodplains. Supplementary planning document. Birmingham City Council, Birmingham

Birmingham City Council (2013) Green living spaces plan. Birmingham City Council, Birmingham

Brendonck L, Jocqué M, Tuytens K, Timms BV, Vanschoenwinkel B (2015) Hydrological stability drives both local and regional diversity patterns in rock pool metacommunities. Oikos 124:741-749

Céréghino R, Boix D, Cauchie HM, Martens K, Oertli B (2014) The ecological role of ponds in a changing world. Hydrobiologia 723:1-6

Chace JF, Walsh JJ (2006) Urban effects on native avifauna: a review. Landsc Urban Plan. 74:46-69

Corti R, Datry T (2015) Terrestrial and aquatic invertebrates in the riverbed of an intermittent river: parallels and contrasts in community organisation. Freshwater Sci 61:1308-1320

Cottenie K (2005) Integrating environmental and spatial processes in ecological community dynamics. Ecol Lett $8: 1175-1182$
Crist TO, Veech JA, Gering JC, Summerville KS (2003) Partitioning species diversity across landscapes and regions: a hierarchical analysis of alpha, beta, and gamma diversity. Am Nat 162:734-743

Crooks KR, Sanjayan M (2006) Connectivity conservation: maintaining connections for nature. In: Crooks KR, Sanjayan M (eds) Connectivity conservation. Cambridge University Press, New York, pp 1-10

Dallimer M, Rouquette JR, Skinner AM, Armsworth PR, Maltby LM, Warren PH, Gaston KJ (2012) Contrasting patterns in species richness of birds, butterflies and plants along riparian corridors in an urban landscape. Divers Distrib 18:742-753

Dallimer M, Tang Z, Bibby PR, Brindley P, Gaston KJ, Davies ZG (2011) Temporal changes in green space in a highly urbanized region. Biol Lett 7:763-766

Davies BR, Biggs J, Williams PJ, Lee JT, Thompson S (2008a) A comparison of the catchment sizes of rivers, streams, ponds, ditches and lakes: implications for protecting aquatic biodiversity in an agricultural landscape. Hydrobiologia 597:7-17

Davies BR, Biggs J, Williams P, Whitfield M, Nicolet P, Sear D, Bray S, Maund S (2008b) Comparative biodiversity of aquatic habitats in the European agricultural landscape. Agr Ecosyst Environ 125:1-8

De Caceres M, Jansen F (2016) Relationship between species and groups of sites. R package version 1.7.6. https://cran.rproject.org/web/packages/indicspecies/indicspecies.pdf

De Marco Jr P, Nogueira DS, Correa CC, Vieira TB, Silva KD, Pinto NS, Bichsel D, Hirota ASV, Vieira RRS, Carneiro FM, de Oliveira AAB, Carvalho P, Bastos RP, Ilg C, Oertli B (2014) Patterns in the organisation of Cerrado pond biodiversity in Brazilian pasture landscapes. Hydrobiologia 723:87-101

Dufrêne M, Legendre P (1997) Species assemblages and indicator species: the need for a flexible asymmetrical approach. Ecol Monogr 67:345-366

EC (1992) Council directive 92/43/EEC on the conservation of natural habitats and of wild fauna and flora, 22/07/1992. Off J Eur Union 206:7-50

EC (2000) Directive 2000/60/EC of the European Parliament and of the Council of 23 October 2000 establishing a framework for Community action in the field of water policy, 22/12/2000. Off J 327(1):1-73

Fahrig L (2003) Effects of habitat fragmentation on biodiversity. Annu Rev Ecol Evol Syst 34:487-515

Gaston KJ, Smith RM, Thompson K, Warren PH (2005) Urban domestic gardens (II): experimental tests of methods for increasing biodiversity. Biodivers Conserv 14:395-413

Gianuca AT, Declerk SAJ, Lemmens P, De Meester L (2016) Effects of dispersal and environmental heterogeneity on the replacement and nestedness components of $\beta$-diversity. Ecology. https://doi.org/10.1002/ecy.1666

Gledhill DG, James P, Davies DH (2008) Pond density as a determinant of aquatic species richness in an urban landscape. Landscape Ecol 23:1219-1230

Gu B, Dong X, Peng C, Luo W, Chang J, Ge Y (2012) The longterm impact of urbanization on nitrogen patterns and dynamics in Shanghai, China. Environ Pollut 171:30-37

Hassall C (2014) The ecology and biodiversity of urban ponds. Wiley Interdiscip Rev 1:187-206 
Hassall C, Anderson S (2015) Storm water ponds can contain comparable biodiversity to unmanaged wetlands in urban areas. Hydrobiologia 745:137-149

Hassall C, Hollinshead J, Hull A (2012) Temporal dynamics of aquatic communities and implications for pond conservation. Biodivers Conserv 21:829-852

Heino J, Bini LM, Andersson J, Bergsten J, Bjelke U, Johansson F (2017) Unravelling the correlates of species richness and ecological uniqueness in a metacommunity of urban pond insects. Ecol Indic 73:422-431

Hering D, Borja A, Carstensen J, Carvalho L, Elliott M, Feld CK, Heiskanen AS, Johnson RK, Moe J, Pont D, Solheim AL (2010) The European water framework directive at the age of 10: a critical review of the achievements with recommendations for the future. Sci Total Environ 408:4007-4019

Hill MJ, Biggs J, Thornhill I, Briers RA, Gledhill DG, White JC, Wood PJ, Hassall C (2017a) Urban ponds as an aquatic biodiversity resource in modified landscapes. Glob Change Biol 23:986-999

Hill MJ, Heino J, Thornhill I, Ryves DB, Wood PJ (2017b) Effects of dispersal mode on the environmental and spatial correlates of nestedness and species turnover in pond communities. Oikos 126:1575-1585

Hill MJ, Hassall C, Oertli B, Fahrig L, Robson BJ, Biggs J, Samways MJ, Usio N, Takamura N, Krishnaswamy J, Wood PJ (in review) New policy directions for global pond conservation. Conserv Lett

Hill MJ, Mathers KL, Wood PJ (2015) The aquatic macroinvertebrate biodiversity of urban ponds in a medium sized European town (Loughborough, UK). Hydrobiologia 760:225-238

Hill MJ, Wood PJ (2014) The macroinvertebrate biodiversity and conservation value of garden and field ponds along a rural - urban gradient. Fundam Appl Limnol 185:107-119

Holway DA, Suarez AV (2006) Homogenization of ant communities in Mediterranean California: the effects of urbanisation and invasion. Biol Conserv 127:319-326

Jeffries M (1988) Measuring Talling's 'element of chance' in pond populations. Freshw Biol 21:383-393

Justus J, Sarkar S (2002) The principle of complementarity in the design of reserve networks to conserve biodiversity: a preliminary history. J Biosci 27:421-435

Kaushal SS, Delaney-Newcomb K, Findlay SE, Newcomer TA, Duan S, Pennino MJ, Sivirichi GM, Sides-Raley AM, Walbridge MR, Belt KT (2014) Longitudinal patterns in carbon and nitrogen fluxes and stream metabolism along an urban watershed continuum. Biogeochemistry 121:23-44

Knop E (2016) Biotic homogenization of three insect groups due to urbanization. Glob Change Biol 22:228-236

LaPoint S, Balkenhol N, Hale J, Sadler J, van der Ree R (2015) Ecological connectivity research in urban areas. Funct Ecol 29:868-878

Laurenco A, Alvarez D, Wang IJ, Velo-Anton G (2017) Trapped within the city: integrating demography, time since isolation and population-specific traits to assess the genetic effects of urbanization. Mol Ecol 26:1498-1514

Loiselle SA, Frost PC, Turak E, Thornhill I (2017) Citizen scientists supporting environmental research priorities. Sci Total Environ 598:937
Lundy L, Wade R (2011) Integrating sciences to sustain urban ecosystem services. Prog Phys Geogr 35:653-669

McGoff E, Dunn F, Cachazo LM, Williams P, Biggs J, Nicolet P, Ewald NC (2016) Finding clean water habitats in urban landscapes: professional researcher vs citizen science approaches. Sci Total Environ 581:105-116

McKinney ML (2006) Urbanization as a major cause of biotic homogenization. Biol Conserv 127:247-260

McKinney ML (2008) Effects of urbanization of species richness: a review of plants and animals. Urban Ecosyst 11:161-176

Ng E, Chen L, Wang Y, Yuan C (2012) A study on the cooling effects of greening in a high density city: an experience from Hong Kong. Build Environ 47:256-271

Noble A, Hassall C (2014) Poor ecological quality of urban ponds in northern England: causes and consequences. Urban Ecosyst 18:1-14

O’Driscoll M, Clinton S, Jefferson A, Manda A, McMillan S (2010) Urbanisation effects on watershed hydrology and instream processes in the Southern United States. Water 2:605-648

Oksanen J, Blanchet FG, Friendly M, Kindt R, Legendre P, McGlinn D, Minchin PR, O'Hara RB, Simpson GL, Solymos P, Henry M, Stevens H, Szoecs E, Wagner H (2017) Vegan: Community ecology package. R package version 2.4-0. http://CRAN.R-project.org/package=vegan

Ortega-Alvarez R, McGregor-Fors I (2009) Living in the big city: effects of urban land-use on bird community structure, diversity, and composition. Landsc Urban Plan 90:189-195

Pauchard A, Aguayo M, Peña E, Urrutia R (2006) Multiple effects of urbanization on the biodiversity of developing countries: the case of a fast-growing metropolitan area (Concepción, Chile). Biol Conserv 127:272-281

Pohlert T (2016) Calculate pairwise multiple comparisons of mean rank sums. $\mathrm{R}$ package version 4.1 . https://cran.rproject.org/web/packages/PMCMR/PMCMR.pdf

Pond Life Project (2000) A landscape worth saving: final report of the pond biodiversity survey of North West England. Pond Life Project, Liverpool

R Development Core Team (2013) R: a language and environment for statistical computing. R Foundation for Statistical Computing, Vienna

Rickbeil GJM, Coops NC, Andrew ME, Bolton DK, Mahony N, Nelson TA (2014) Assessing conservation regionalisation schemes: employing a beta diversity metric to test the environmental surrogacy approach. Divers Distrib 20:503-514

Roy AH, Rosemond AD, Paul MJ, Leigh DS, Wallace JB (2003) Stream macroinvertebrate response to catchment urbanization (Georgia, USA). Freshw Biol 48:329-346

Scheffer M, van Geest GJ, Zimmer K, Jeppersen E, Sondergaard M, Butler MG, Hanson MA, Declerck S, De Meester L (2006) Small habitat size and isolation can promote species richness: second-order effects on biodiversity in shallow lakes and ponds. Oikos 112:227-231

Seto KC, Guneralp B, Hutyra LR (2012) Global forecasts of urban expansion to 2030 and direct impacts on biodiversity and carbon pools. PNAS 109:16083-16088 
Shao M, Tang X, Zhang Y, Li W (2006) City clusters in China: air and surface water pollution. Front Ecol Environ 4:353-361

Simaika JP, Samways MJ, Frenzel PP (2016) Artificial ponds increase local dragonfly diversity in a global biodiversity hotspot. Biodivers Conserv 25:1921-1935

Smith RF, Alexander LC, Lamp WO (2009) Dispersal by terrestrial stages of stream insects in urban watersheds: a synthesis of current knowledge. J N Am Benthol Soc 28:1022-1037

Socolar JB, Gilroy JJ, Kunin WE, Edwards DP (2016) How should beta-diversity inform biodiversity conservation. Trends Ecol Evol 31:67-80

Sol D, Gonzalez-Lagos C, Moreira D, Maspons J, Lapiedra O (2014) Urbanisation tolerance and the loss of avian diversity. Ecol Lett 17:942-950

Stepenuck KF, Crunkilton RL, Wang L (2002) Impacts of urban landuse on macroinvertebrate communities in southeastern Wisconsin streams. JAWRA J Am Water Resour Assoc 38:1041-1051

Stewart RI, Andersson GK, Brönmark C, Klatt BK, Hansson LA, Zülsdorff V, Smith HG (2017) Ecosystem services across the aquatic-terrestrial boundary: linking ponds to pollination. Basic Appl Ecol 28:13-20

Streutker DR (2003) Satellite-measured growth of the urban heat island of Houston, Texas. Remote Sens Environ 85:282-289

Terando AJ, Costanze J, Belyea C, Dunn RR, McKerrow A, Collazo JA (2014) The southern megalopolis: using the past to predict the future of urban sprawl in the southeast US. PLoS ONE 9:e102261

Thornhill I (2013) Water quality, biodiversity and ecosystem functioning in ponds across an urban land-use gradient in Birmingham. University of Birmingham, U.K

Thornhill I, Batty L, Death RG, Friberg NR, Ledger ME (2017a) Local and landscape scale determinants of macroinvertebrate assemblages and their conservation value in ponds across and urban land-use gradient. Biodivers Conserv 26:1065-1086

Thornhill I, Batty L, Hewitt M, Friberg NR, Ledger ME (2017b) The application of graph theory and percolation analysis for assessing change in the spatial configuration of pond networks. Urban Ecosyst. https://doi.org/10.1007/s11252017-0724-8

Tratalos J, Fuller RA, Warren PH, Davies RG, Gaston KJ (2007) Urban form, biodiversity potential and ecosystem services. Lanscape Urban Plan 83:308-317

UKNEA (2011) The UK national ecosystem assessment technical report. UNEP-WCMC, Cambridge

Usio N, Imada M, Nakagawa M, Akasaka M, Takamura N (2013) Effects of pond draining on biodiversity and water quality of farm ponds. Conserv Biol 27:1429-1438

Vad CF, Péntek AL, Cozma NJ, Földi A, Tóth A, Tóth B, Böde NA, Móra A, Ptacnik R, Ács É, Zsuga K (2017) Wartime scars or reservoirs of biodiversity? The value of bomb crater ponds in aquatic conservation. Biol Conserv 209:253-262

Vaughan IP, Ormerod SJ (2012) Large-scale, long-term trends in British river macroinvertebrates. Glob Change Biol 18:2184-2194

Viana DS, Figuerola K, Schwenk K, Manca M, Hobaek A, Mjelde M, Preston CD, Gornall R, Croft JM, King RA, Green AJ, Santamaria L (2016) Assembly mechanisms determining high species turnover in aquatic communities over regional and continental scales. Ecography 39:281-288

Walters DM, Leigh DS, Bearden AB (2003) Urbanization, sedimentation and the homogenization of fish assemblages in the Etowah river basin, USA. Hydrobiologia 494:5-10

Williams P, Whitfield M, Biggs J, Bray S, Fox G, Nicolet P, Sear DA (2003) Comparative biodiversity of rivers, streams, ditches and ponds in an agricultural landscape in Southern England. Biol Conserv 115:329-341

Wood PJ, Greenwood MT, Barker SA, Gunn J (2001) The effects of amenity management for angling on the conservation value of aquatic invertebrate communities in old industrial mill ponds. Biol Conserv 102:17-29

Wright SJ, Calderón O, Hernandéz A, Detto M, Jansen PA (2016) Interspecific associations in seed arrival and seedling recruitment in a Neotropical forest. Ecology 97:2780-2790 